\title{
Global health diplomacy: a solution to meet the needs of disabled people in Yemen
}

\author{
Saeed Shahabi ${ }^{1^{*}} \mathbb{D}$, Maryam Jalali ${ }^{2}$ and Kamran Bagheri Lankarani ${ }^{1}$
}

\begin{abstract}
People with disabilities (PWD) are one of the most vulnerable groups in society during armed conflicts. According to the statistics, four million persons with disability live in Yemen. Lack of access and the use of rehabilitation services make PWD unable to retrieve their social and economic roles, which would have substantial negative impacts both on their families and community. The conflict escalation, an increase in the number the of displaced, COVID-19 pandemic, an increase in non-communicable diseases, and the exacerbation of poverty and malnutrition have rapidly enhanced the population at risk of disability in Yemen. Accordingly, effective and comprehensive approaches such as global health diplomacy (GHD) should be considered to meet the emerged needs. GHD seeks to address the common challenges in the global health system by involving all key stakeholders and establishing negotiations and diplomatic dialogue among official actors. Given the presence of various regional and international actors in Yemen and the examples of the successful use of GHD under conflict and post-conflict conditions in Iraq and Afghanistan, the use of diplomacy is crucial to respond to the needs of PWD in this war-torn country appropriately.
\end{abstract}

Keywords: Global health diplomacy, Disabled people, Rehabilitation, Yemen

Since 2014, following the conflicts between the Houthis and supporters of President Abdrabbuh Mansur Hadi, Yemen experienced chaos and clashes. Furthermore, as of 25 March 2015, fighting escalated with the intervention of a Saudi-led military coalition seeking government support in Aden [1]. About 112,000 persons were killed during this conflict, of whom 12,000 were civil persons [2]. In addition, there have been many more indirect deaths as a result of disrupted health services and lack of food supplies and other key services. The over-five-year conflict has had a severe impact on public infrastructures, with $85 \%$ of the country's population in the need of humanitarian assistance [3]. About half of the country's health facilities are

\footnotetext{
* Correspondence: Saeedshahabi1@gmail.com

${ }^{1}$ Health Policy Research Center, Institute of Health, Shiraz University of Medical Sciences, Shiraz, Iran

Full list of author information is available at the end of the article
}

currently fully operational $[4,5]$. Disastrously, using explosive weapons in crowded and populated regions is one of the unfortunate features of the war [6]. One of the biggest world's humanitarian crisis is now occurring in Yemen.

People with disabilities (PWD) are one of the most vulnerable groups during conflicts [7]. According to the 2016 Global Burden of Disease (GBD) results, Yemen had the highest disability burden in accordance with the years lived with disability (YLDs) among 195 countries [8]. Although there is no exact statistics on the number of PWD in Yemen, it is estimated that four million persons with disability live there [4,9]. Notably, since explosive weapons cause more severe and complex disabilities such as amputations and spinal cord injuries, the use of timely, specialized, and long-term services is crucial [10]. Meanwhile, significant damage to Yemen's health system and infrastructures has left rehabilitation services such as physiotherapy,

(c) The Author(s). 2020 Open Access This article is licensed under a Creative Commons Attribution 4.0 International License, which permits use, sharing, adaptation, distribution and reproduction in any medium or format, as long as you give appropriate credit to the original author(s) and the source, provide a link to the Creative Commons licence, and indicate if changes were made. The images or other third party material in this article are included in the article's Creative Commons licence, unless indicated otherwise in a credit line to the material. If material is not included in the article's Creative Commons licence and your intended use is not permitted by statutory regulation or exceeds the permitted use, you will need to obtain permission directly from the copyright holder. To view a copy of this licence, visit http://creativecommons.org/licenses/by/4.0/ The Creative Commons Public Domain Dedication waiver (http://creativecommons.org/publicdomain/zero/1.0/) applies to the data made available in this article, unless otherwise stated in a credit line to the data. 
prosthetics and orthotics, and occupational therapy unavailable [7]. Lack of access to rehabilitation services makes PWD unable to retrieve their social and economic roles, which can have substantial negative impacts both on their families and community.

In response, several international organizations such as Humanity and Inclusion (also known as Handicap International) have initiated various programs to strengthen the rehabilitation services in Yemen [10]. Humanity and Inclusion is providing rehabilitation services to PWD and those injured through mobile and fixed disability teams, and it also operates in nine health centers to meet the needs of the vulnerable groups, especially PWD [11]. The UN Children's Fund (UNICEF) is another active actor in this field in Yemen, with a strong focus on children with disabilities [12]. For example, over 100 children with disability across the country have received psychosocial and rehabilitation services such as physical therapy and assistive devices [12]. The International Committee of the Red Cross (ICRC) also helps PWD in Yemen by promoting physical rehabilitation centers in four cities (in Sana'a, Aden, Mukalla, and Taiz), including supplying prostheses and orthoses [13].

Despite all the efforts, the conflict escalation in recent years, the increase in the number of displaced residents
[14], the COVID-19 pandemic, increases in noncommunicable diseases such as Neonatal Congenital Anomalies [15], and the exacerbation of poverty and malnutrition [16] have rapidly enhanced the population at risk of disability in Yemen. Accordingly, it is necessary to respond effectively to the needs of PWD in this war-torn country by adopting effective international policies and tools such as global health diplomacy (GHD). GHD seeks to address the common challenges in the global health system by involving all key stakeholders and establishing negotiations and diplomatic dialogues among the official actors [17]. As presented in Fig. 1, GHD consists of three levels (namely core diplomacy, multi-stakeholder diplomacy, and informal diplomacy) [18].

Some examples of the successful use of GHD include multilateral tuberculosis programs in Iraq, in which international collaborations and diplomatic efforts led to better coverage and access to tuberculosis services [19]. A study in Afghanistan showed how GHD strengthened the implementation and delivery of the international health programs under conflict and post-conflict conditions [20]. A key element of GHD is to ensure that all targeted individuals, especially vulnerable groups such as PWD, have access to health services in crisis settings [21].

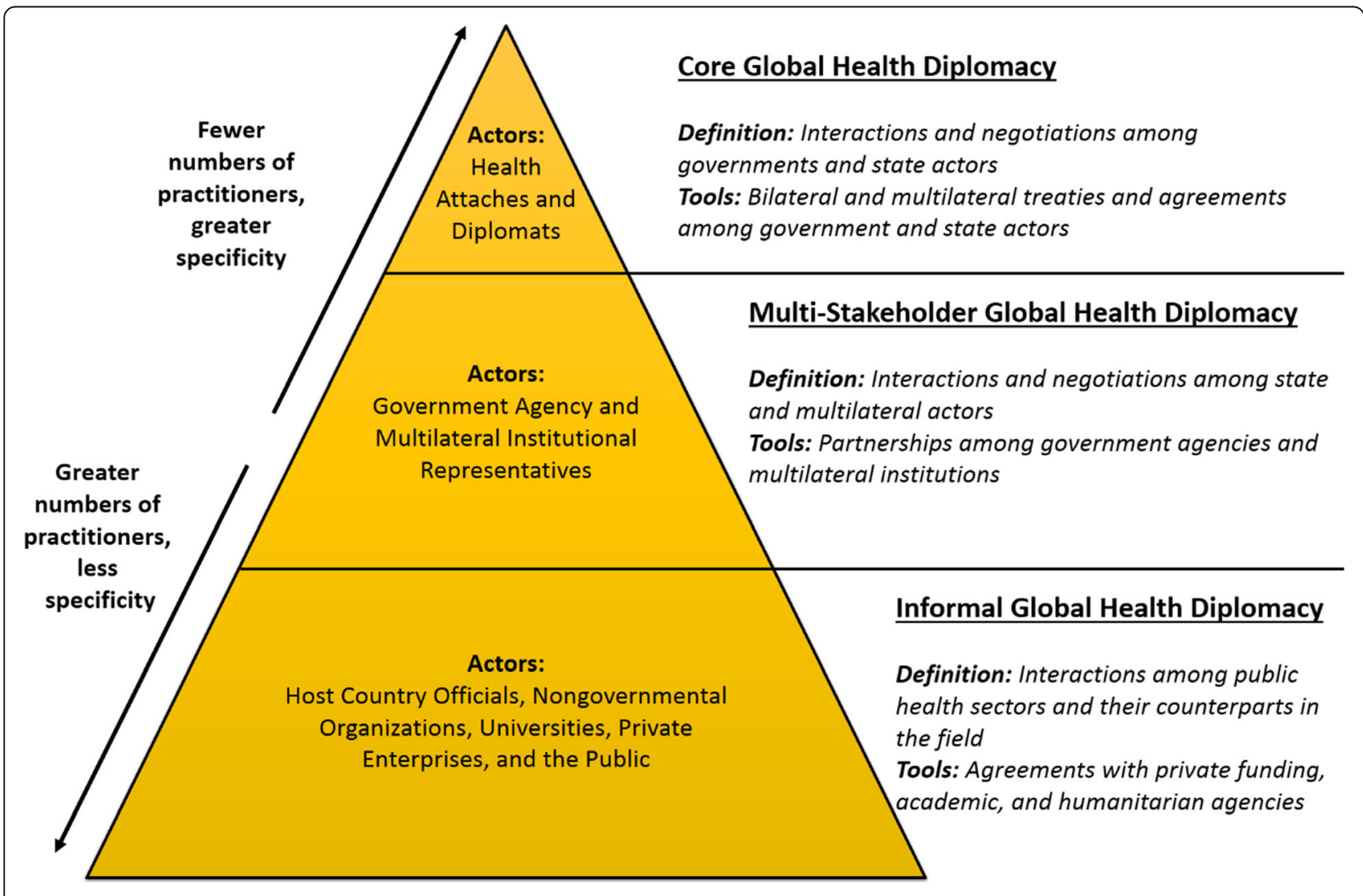

Fig. 1 Three levels of Global Health Diplomacy (adapted from Katz et al. Defining Health Diplomacy: Changing Demands in the Era of Globalization) 
In accordance with the three levels of GHD pyramid, the core diplomacy implies negotiations and interactions among governments and international organizations to reach an agreement [18]. Therefore, addressing the challenges of PWD in Yemen at the high-level of UN and WHO meetings, such as Prevention and Control of Non-Communicable Diseases and The Paris Declaration on Aid Effectiveness [22, 23], could facilitate greater involvement of state actors and international cooperation. Furthermore, at the multi-stakeholder diplomacy level, the active participation of relevant national ministries such as the Ministry of Health, the Ministry of Foreign Affairs, academics, national research centers, and also regional organizations (such as The WHO Regional Office for the Eastern Mediterranean) is of great importance to receive advocacy, conduct research studies, hold international conferences, and influence the negotiations and policies of other countries [18]. In this regard, Rehabilitation 2030: A call for action, developed by the WHO, considers effective cooperation between stakeholders and the receipt of foreign assistance as a prerequisite for the provision of rehabilitation services to PWD, especially in poor countries [24]. In accordance with the third level of the pyramid (informal diplomacy), organizing and empowering the PWD campaigns, nongovernmental organizations, and other private institutions as well as proper interaction with foreign counterparts can be a stimulus to this dimension [18]. Campaigns against alcohol and tobacco consumption are some successful examples in this regard [23].

Numerous meetings and summits on Yemen are held annually worldwide to try and establish peace and respond to the needs of individuals as incorporating the PWD-related issues in diplomatic negotiations can facilitate an optimal response to the rising needs. However, increased awareness about the challenges of PWD and potential solutions is also needed among diplomats and others involved in such efforts. Rehabilitation experts, relevant non-governmental organizations, and patient councils must be involved in meetings to provide a clear picture of the needs of PWD in conflicts such as Yemen. In general, international collaboration via active health diplomacy is required to deal with the PWD challenges in war-torn Yemen.

\section{Abbreviations \\ GBD: Global Burden of Disease; YLDs: Years lived with disability; UNICEF: United Nations International Children's Emergency Fund; ICRC: International Committee of the Red Cross; GHD: Global Health Diplomacy}

\section{Acknowledgements}

None.

\section{Authors' contributions}

All authors participated in the design, writing, and rewriting of the manuscript. The author(s) read and approved the final manuscript.
Funding

None.

Availability of data and materials

Not applicable.

Ethics approval and consent to participate

Not applicable.

Consent for publication

Not applicable.

Competing interests

I declare no competing interests.

\section{Author details}

${ }^{1}$ Health Policy Research Center, Institute of Health, Shiraz University of Medical Sciences, Shiraz, Iran. ${ }^{2}$ Rehabilitation Research Center, Department of Orthotics and Prosthetics, School of Rehabilitation Sciences, Iran University of Medical Sciences, Tehran, Iran.

Received: 30 July 2020 Accepted: 18 September 2020

Published online: 24 September 2020

References

1. El Bcheraoui C, Jumaan AO, Collison ML, Daoud F, Mokdad AH. Health in Yemen: losing ground in war time. Glob Health. 2018;14(1):42.

2. Yemen's rebels: Saudi coalition airstrike kills 13 civilians. https://apnews.com/ b7f039269a394b7aa2b46430e3d9b6bc. Accessed 25 July 2020.

3. World Food Programme. WFP Yemen Situation Report. https://reliefweb.int/ sites/reliefweb.int/files/resources/YEMEN_\%20This\%20is\%20the\%20world\%2 75\%20largest\%20food\%20crisis_.pdf. Accessed 25 July 2020.

4. Yemen: 2019 Humanitarian Needs Overview 2019. https://reliefweb.int/ report/yemen/yemen-2019-humanitarian-needs-overview-enar. Accessed 25 July 2020 .

5. MSF hospital destroyed by airstrike. https://www.msf.org/yemen-msfhospital-destroyed-airstrikes. Accessed 25 July 2020.

6. Dathan J. Explosive Violence Monitor 2018. Action on Armed Violence: London; 2019. https://aoav.org.uk/wp-content/uploads/2019/05/ExplosiveViolence-Monitor-2018-v5.pdf.

7. Death Sentence to Civilians: The Long-Term Impact of Explosive Weapons in Populated Areas in Yemen. Lyon: Humanity \& Inclusion; 2019. https:// blog.hi.org/wp-content/uploads/2020/06/Study2020_Rapport-YEMENEWIPA_EN_Web.pdf.

8. Vos T, Abajobir AA, Abate KH, Abbafati C, Abbas KM, Abd-Allah F, et al. Global, regional, and national incidence, prevalence, and years lived with disability for 328 diseases and injuries for 195 countries, 1990-2016: a systematic analysis for the global burden of disease study 2016. Lancet. 2017:390(10100):1211-59.

9. Yemen conflict death toll nears 650 , with UN rights office spotlighting the plight of 3 million disabled. UN News. https://news.un.org/en/ story/2015/05/497832-yemen-conflict-death-toll-nears-650-un-rightsoffice-spotlighting-plight-3. Accessed 25 July 2020.

10. Urgent need for rehabilitation services in Yemen. Lyon: Humanity \& Inclusion. https://humanity-inclusion.org.uk/en/news/urgent-need-forrehabilitation-services-in-yemen. Accessed 25 July 2020.

11. Yemen. Lyon: Humanity \& Inclusion. https://hi.org/en/country/yemen. Accessed 25 July 2020

12. Qasim A: Aswan: the Cinderella of Yemen. 2018. https://www.unicef.org/ yemen/stories/aswan-cinderella-yemen.

13. The scars of war: Yemen's disabled. Geneva: International Committee of The Red Cross; 2016. https://www.icrc.org/en/document/scars-waryemens-disabled.

14. Conflict affected Yemenis homeless \& desperately struggling to find safe shelter - urgent support needed. New York: Reliefweb. https://reliefweb.int/ report/yemen/conflict-affected-yemenis-homeless-desperately-strugglingfind-safe-shelter-urgent. Accessed 25 July 2020.

15. Abol-Gaith FM, Ismail NA, Al-Mutawakel AA. The Neonatal Congenital Anomalies: Incidence and Risk Factors Before and After the war at AlThawrah Hospital-Sana'a, Yemen. Assiut Scientific Nurs J. 2019;7(19):32-40. 
16. Al-Dheeb N, Ziolkovska A, Chitekwe S. Experiences of implementing CMAM in Yemen and number of deaths averted. Field Exch. 2018:58:64.

17. Gómez EJ. The Politics of Global Health Diplomacy: Conceptual, Theoretical, and Empirical Lessons from the United States, Southeast Asia, and Latin America. Glob HIV/AIDS Politics, Policy, Activism: Persistent Challenges Emerging Issue. 2013;3:73.

18. Katz R, Kornblet $S$, Arnold G, Lief E, Fischer JE. Defining health diplomacy: changing demands in the era of globalization. Milbank Q. 2011;89(3):503-23

19. Kevany S, Jaf P, Workneh NG, Dalo MA, Tabena M, Rashid S, et al. Global health diplomacy in Iraq: international relations outcomes of multilateral tuberculosis programmes. Med Confl Surviv. 2014;30(2):91-109.

20. Kevany S, Sahak O, Workneh NG, Saeedzai SA. Global health diplomacy investments in Afghanistan: adaptations and outcomes of global fund malaria programs. Med Confl Surviv. 2014:30(1):37-55.

21. Mackey TK, Strathdee SA. Responding to the public health consequences of the Ukraine crisis: an opportunity for global health diplomacy. J Int AIDS Soc. 2015;18(1):19410.

22. Kickbusch I, Lister G, Told M, Drager N. Global health diplomacy: concepts, issues, actors, instruments, fora and cases. Berlin: Springer Science \& Business Media; 2012.

23. Afshari M, Ahmadi Teymourlouy A, Asadi-Lari M, Maleki M. Global Health diplomacy for noncommunicable diseases prevention and control: a systematic review. Glob Health. 2020;16:1-16.

24. Gimigliano F, Negrini S. The World Health Organization "rehabilitation 2030a call for action". Eur J Phys Rehabil Med. 2017:53(2):155-68.

\section{Publisher's Note}

Springer Nature remains neutral with regard to jurisdictional claims in published maps and institutional affiliations.

Ready to submit your research? Choose BMC and benefit from:

- fast, convenient online submission

- thorough peer review by experienced researchers in your field

- rapid publication on acceptance

- support for research data, including large and complex data types

- gold Open Access which fosters wider collaboration and increased citations

- maximum visibility for your research: over $100 \mathrm{M}$ website views per year

At BMC, research is always in progress.

Learn more biomedcentral.com/submissions 